\title{
Immobilized Polyextremophilic a-Amylase of Bacillus mycoides for Citric Acid Production Using Starch
}

\author{
A.D. Bholay, Deshmukh Swateja Sanjay* and Joseph Angeline Wilson \\ Department of Microbiology, K.T.H.M College, Nashik, \\ Savitribai Phule Pune University, MS, India \\ *Corresponding author
}

\begin{abstract}
A B S T R A C T
Immobilization is a wide spread technique in the last three decades. It is a powerful method which can improve properties of enzymes like stability, activity, resistance to inhibition due to the by-products in fermentation and its quick recovery. In the present investigation a halophilic organism Bacillus mycoides producing $\alpha$-amylase was isolated from saline water. A mixed fermenter system was made for citric acid production using starch. $\alpha$-amylase of Bacillus mycoides was used for conversion of starch into glucose and further Aspergillus niger was used for conversion of glucose into citric acid. The enzyme activity of free enzyme and free cells was assayed by DNSA method. Effect of gel concentration, cell concentration and enzyme concentration was studied for both immobilized cells and enzyme. The activity of immobilized enzyme was high by $78 \%$ as compared to that of immobilized cells at $1.5 \%$ of gel concentration. Activity of enzyme and cell was high at $1.5 \mathrm{ml}$ of its concentration. The activity of enzyme was high as compared to cell by $75.5 \%$. It was found that the enzyme and cells were stable and gave high activity at $6.0 \mathrm{pH}$ and $60^{\circ} \mathrm{C}$ after immobilization. Then under all optimum conditions immobilized beads of Bacillus mycoides cells and $\alpha$-amylase beads were paced in $20 \%$ starch solution and beads of Aspergillus niger were added into it for citric acid production. The productivity for starch hydrolysis and citric acid was then checked in different bioreactors and was found maximum in Air lift- fermenter which was $73 \%$ and $80 \%$ high as compared with shake flask and column reactor.
\end{abstract}

\section{Introduction}

The term immobilized enzymes refers to enzyme physically restricted or constrained in a certain defined region of space with retention of their catalytic activities and which can be used sustainably. The constituents of an immobilized enzyme system consist of the enzyme, the matrix and the mode of attachment. The attachment of the enzyme to the support depends upon the stability of the covalent bonds by reversible physical adsorption and ionic linkages (Brena Breatriz et al., 2006).

Immobilized enzyme was discovered since 1916, when Nelson and Griffin discovered that invertase when adsorbed to charcoal has the ability to hydrolyze sucrose (Ahmad Razi et al., 2015). 
The reusability and stability of the immobilized enzyme was identified by Grubhofer and Schelth, reported the covalent immobilization of various enzymes (Nisha et al., 2012). The easy contact with the substrate and non-detachable from the inert matrix support, increases the benefits of immobilization. It is a technique which is preferred over free enzyme catalysis giving the advantages like increasing enzyme's stability, easy separation of reactant and product, repeated use of a single batch of enzyme which eventually saves the enzyme, toil and overhead costs (Maheshwari Uma et al., 2014).

Adverse conditions are too harsh for normal life to exist, but a variety of bacteria and fungi can survive.

These organisms have evolved to exist in these extreme environment and fall into a number of different categories, including halotolerant, moderate, borderline and extremely halophilic (Esawy Mona Abdeltawab et al., 2014). Halophilic bacteria are commonly found in natural environments containing significant concentration of $\mathrm{NaCl}$ (Irshad Aarzoo et al., 2013).

Among halophilic microorganisms are a variety of heterotrophic and methanogenic archaea; photosynthetic lithotrophs, and hetrotrophic bacteria and photosynthetic and heterotrophic eukaryotes (Azhar Mohsin et al., 2014). Comparatively halophilic organisms grow optimally between 0.5-2.5 M salt concentration (Todkar Sandip et al., 2012). The word halophile is derived from Greek meaning "salt loving" (Kumar Sumit et al., 2012).

Amylases are normally constitutive enzymes. Very few alpha amylases have been studied from halophilic origin (Kumar Sumit et al., 2012). Amylases are enzymes, which hydrolyze starch molecule to give diverse products including dextrin and progressively smaller polymers composed of glucose units (Singh Pushpendra et al., 2012). Amylases are widely present in microorganisms, plants and animals, and have found applications in numerous industries including starch liquefaction, brewing, food, paper, textile and pharmaceuticals (Tavano Olga Lusia et al., 2013; Abdu Al- ZaZaee Mohammad et al., 2011).

Two major classes of amylases have been identified namely $\alpha$-amylase and $\beta$-amylase (Prabhakaran et al., 2009). $\alpha$-amylase is most abundantly found in humans and other mammals (Raghu et al., 2015). The production and thermo-stability of $\alpha$-amylase is highly dependent upon the type of strain, composition of media, method of cultivation, cell growth, nutrient requirement, metal ions, $\mathrm{pH}$, incubation temperature and time of incubation. The enzyme has been shown to be activated in presence of $\mathrm{Ca}^{2+}$ and $\mathrm{K}^{+}$while inhibited by $\mathrm{Co}^{2+}$ and $\mathrm{Cu}^{2+}$ (Abdu Al- ZaZaee Mohammad et al., 2011).

In this study, the efforts have been made to isolate the halophile with good $\alpha$-amylase activity in the presence of starch as a carbon source.

The parameters influencing the amylase productivity such as time, temperature and $\mathrm{pH}$ were studied. The enzyme was partially purified and successfully immobilized in sodium alginate. The parameters influencing the amylase activity of immobilized enzyme such as sodium alginate concentrations, enzyme concentrations and cell concentrations were studied. The unconventional production of citric acid form starch using immobilized bacterial isolate and immobilized Aspergillus niger in different bioreactors such as shake flask, column reactor and air-lift reactor was studied. 


\section{Materials and Methods}

\section{Isolation and screening of bacteria}

The sea water sample collected from sea shore was enriched in selective medium. For primary screening, isolates were streaked over the starch medium containing $1 \%$ starch, $0.5 \%$ yeast extract, $0.5 \%$ peptone, $0.01 \% \mathrm{MgSO}_{4}$, $5 \% \mathrm{NaCl}$ and $2 \%$ agar at $\mathrm{pH} 6.0$ for the selection of starch degrading organism. The plates were incubated at $30^{\circ} \mathrm{C}$ for $24 \mathrm{hrs}$ and were flooded with Gram's iodine solution ( $2 \%$ iodine and $0.2 \%$ potassium iodide) (Abdu AlZaZaee Mohammad et al., 2011; Suman et al., 2010). Organism giving largest hydrolysis zone was considered.

\section{Characterization of isolated organism}

The characterization of isolated organism was done by its morphological and biochemical characters, Gram's staining and identified as per Bergey's manual and further conformed by VITEK 2 system version 05.02. The Aspergillus nigerNCIM-1246 was procured from NCL, Pune, India.

\section{Polyextremophylic nature of organism}

The polyextremophylic nature of isolate was determined by culturing in nutrient medium with varying salt concentrations $(0.5 \%, 2 \%$, $5 \%$ and $10 \%)$, at different temperature $(30,40$, 50,60 and $\left.70^{\circ} \mathrm{C}\right)$ and $\mathrm{pH}(5,6,7$ and 8$)$.

\section{Fermentation process}

For large scale production of the alpha amylase, fermentation was carried out in an baffled Erlenmeyer flask containing starch medium of composition - $20 \%$ starch, $0.5 \%$ yeast extract, $0.5 \%$ peptone, $0.01 \% \quad \mathrm{MgSO}_{4}$ and $5 \% \mathrm{NaCl}$ adjusted at $\mathrm{pH}$ 6.0. The flasks were sterilized and then seeded with 5\% inoculum of $24 \mathrm{hrs}$ old bacterial culture and incubated at $30^{\circ} \mathrm{C}$ for $72 \mathrm{hrs}$ (Mostafa Yasser et al., 2014) on shaking incubator.

\section{Partial purification of enzyme}

The fermented broth was centrifuged at $5000 \mathrm{rpm}$ for $20 \mathrm{mins}$ at $4^{\circ} \mathrm{C}$. The supernatant (crude enzyme) was further used for salt precipitation by $80 \%$ ammonium sulphate. The precipitate was centrifuged at 10,000 rpm for $20 \mathrm{mins}$ at $4^{\circ} \mathrm{C}$. The resultant pellet was then dissolved in $0.2 \mathrm{M} \mathrm{PO}_{4}$ buffer $(\mathrm{pH} 8)$, dialyzed and lyophilized (Abdu Al- ZaZaee Mohammad et al., 2011).

\section{$\alpha$-Amylase enzyme assay}

a-Amylase was assayed as described by kirankanthi et al., 2012. The activity of $\alpha$ amylase was determined by using starch as the substrate. The amount of reducing sugar released was measured by using 3,5 dinitrosalicylic acidusing maltose as the standard (Lahiri Preeti et al., 2015; Kiran Kanthi et al., 2012). In this study, $0.5 \mathrm{ml}$ of starch solution $(20 \% \mathrm{w} / \mathrm{v})$ in phosphate buffer and $0.5 \mathrm{ml}$ of enzyme solution was incubated at $30^{\circ} \mathrm{C}$ for $10 \mathrm{mins}$ in hot water bath. The enzymatic reaction was stopped by adding $1 \mathrm{ml}$ of DNSA reagent and incubated in boiling water bath for $15 \mathrm{mins}$ and absorbance was taken at 530nm. An enzyme blank with DNSA added prior to enzyme addition served as control. Effect of enzyme activity at different $\mathrm{pH}$ (3-8) and temperature $\left(30-70^{\circ} \mathrm{C}\right)$ was studied.

\section{Immobilization of halophile}

The alginate entrapment of cells and enzyme was performed according to the method suggested by Mustafa Yasser et al., (2014). One $\mathrm{ml}$ of cell suspension $\left(4 \times 10^{8} \mathrm{CFU} / \mathrm{ml}\right.$ gel $)$ was mixed in $2 \%$ alginate solution. Beads of this solution were made in $3.5 \%(\mathrm{w} / \mathrm{v}) \mathrm{CaCl}_{2}$ solution on a magnetic starrier. In this study, 
the parameters influencing the activity of $\alpha$ amylase enzyme such as sodium alginate gel concentrations $(1.5 \%, 2 \%$ and $2.5 \%)$, cell concentrations $\quad\left(2 \times 10^{8} \mathrm{CFU} / \mathrm{ml}, \quad 4 \times 10^{8}\right.$ $\left.\mathrm{CFU} / \mathrm{ml}, \quad 8 \times 10^{8} \mathrm{CFU} / \mathrm{ml}\right)$, and enzyme (partially purified enzyme) concentrations $(0.4 \mathrm{ml}, 0.6 \mathrm{ml}$ and $0.8 \mathrm{ml})$ were studied.

\section{Immobilization of Aspergillus niger}

Aspergillus niger was grown in Sabouraud Dextrose Broth at $28^{\circ} \mathrm{C}$ for $48 \mathrm{hrs}$ and then medium was centrifuged at 5000rpm for $15 \mathrm{mins}$ at $4^{\circ} \mathrm{C}$. The pellet was suspended in Tris buffer. One $\mathrm{ml}$ of this suspension $\left(3 \times 10^{9}\right.$ spores) was mixed in $2 \%$ alginate solution and beads were made in $3.5 \% \mathrm{CaCl}_{2}$ solution.

\section{Design and operation of bioreactors}

\section{Shake flask}

Shake flask also called as Erleynmeyer flask. $1 \%$ starch as substrate was added into flask along with immobilized beads of halophilic organism, kept on shaker at 200rpm.

Sample was withdrawn after every $24 \mathrm{hrs}$ and checked for formation of glucose by DNSA method.

Immobilized Aspergillus niger are then added to the flask and then incubated on shaker and production of citric acid was assayed gravimetrically following Marrier and Boulet method (Pandey et al., 2013).

\section{Column reactor}

Column reactor consists of a column of 10inch in length and 0.5 inch width. The column was filled with immobilized beads. Substrate was than filled in the column and kept in contact with the beads without shaking. Sample was withdrawn after every $24 \mathrm{hrs}$ and checked for substrate conversion.

\section{Airlift reactor}

It is also called as bubble column reactor. It has column, immobilized bed and has an additional apparatus called sparger for aeration. Sparger was placed at the bottom of the column, it was than filled with immobilized beads. Column was than filled with substrate i.e., $20 \%$ starch solution and continuously supplied with air. Samples were withdrawn after every $24 \mathrm{hrs}$ and checked for glucose production.

\section{Results and Discussion}

\section{Isolation and screening of the bacteria}

Four isolates $\left(\mathrm{A}_{1}, \mathrm{~A}_{2}, \mathrm{~A}_{3}\right.$ and $\left.\mathrm{A}_{4}\right)$ of halophilic bacteria were obtained. During the screening the isolate $\mathrm{A}_{4}$ gave the maximum hydrolysis zoneof $17 \mathrm{~mm}$ and this organism was then further characterized.

\section{Characterization of isolated organism}

The isolated organism was identified as Bacillus mycoides and it was the same species as reported by Suribabu et al., (2014). The identification of organism by VITEK system is shown in table 1 .

\section{Polyextremophylic nature of organism}

The organism was found to be thermophilic tolerating $60^{\circ} \mathrm{C}$ temperature and grow well at pH6.0 with $5 \%$ of salt concentration indicated its polyextremophilic nature.

\section{Enzyme activity of free $\alpha$-amylase and free cell}

The enzyme activity of free enzyme was high as compared to free cell. The enzyme activity was high after the incubation of $48 \mathrm{hrs}$ and further the decrease in enzyme activity was observed (Table 2 and Fig. 1). 
Table.1 Identification of potent isolate by VITEK system

\begin{tabular}{|c|c|c|c|c|c|c|c|c|c|c|c|c|c|c|c|c|c|}
\hline \multicolumn{12}{|c|}{ 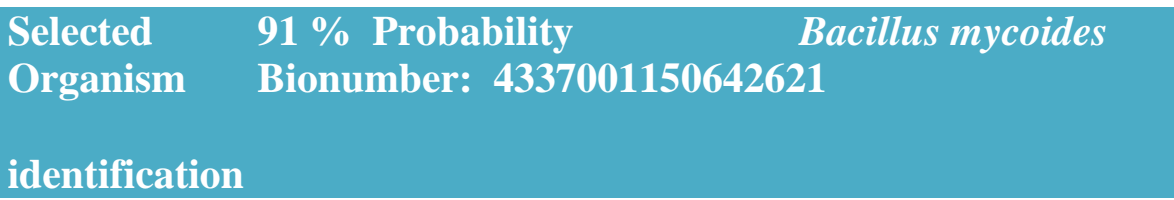 } & \multicolumn{3}{|c|}{ Confidence: } & \multicolumn{3}{|c|}{ very good } \\
\hline \multicolumn{18}{|c|}{$\begin{array}{l}\text { Contraindicating Typical Biopattern (s) } \\
\text { Bacillus mycoides } \\
\text { BNAG(92), Le }\end{array}$} \\
\hline \multicolumn{18}{|c|}{ Biochemical details: } \\
\hline 1 & BXYL & - & 3 & LysA & - & 4 & AspA & $\begin{array}{l}(+ \\
)\end{array}$ & 5 & LeuA & + & 7 & PheA & + & 8 & ProA & - \\
\hline 9 & BGAL & + & 10 & PyrA & + & 11 & AGAL & - & 12 & AlaA & + & 13 & TyrA & + & 14 & BNAG & + \\
\hline$\overline{15}$ & APPA & - & 18 & $\begin{array}{l}\mathrm{CDE} \\
\mathrm{X}\end{array}$ & - & 19 & dGAL & - & 21 & GLYG & - & 22 & INO & - & 24 & MdG & $(-)$ \\
\hline 25 & ELLM & + & 26 & $\mathrm{MdX}$ & - & 27 & AMAN & - & 29 & MTE & + & 30 & GlyA & - & 31 & dMAN & - \\
\hline 32 & dMNE & + & 34 & dMLZ & - & 36 & NAG & + & 37 & PLE & - & 39 & IRHA & - & 41 & BGLU & - \\
\hline 43 & $\begin{array}{l}\text { BMA } \\
\mathrm{N}\end{array}$ & - & 44 & PHC & + & 45 & \begin{tabular}{|l} 
PVAT \\
E
\end{tabular} & $\begin{array}{l}(+ \\
)^{\prime}\end{array}$ & 46 & AGLU & $(-)$ & 47 & dTAG & - & 48 & dTRE & + \\
\hline 50 & INU & (- & 53 & dGLU & + & 54 & dRIB & - & 55 & $\mathrm{PSCNa}$ & - & 58 & $\begin{array}{l}\mathrm{NaCl} \\
6.5 \%\end{array}$ & + & 59 & KAN & + \\
\hline 60 & OLD & - & 61 & ESC & + & 62 & TTZ & - & 63 & POLYB_R & + & & & & & & \\
\hline
\end{tabular}

Table.2 Enzyme activity of free $\alpha$-amylase and free cell

\begin{tabular}{|c|c|c|}
\hline \multirow{2}{*}{ Time in hrs } & \multicolumn{2}{|c|}{ Enzyme activity (mM/m//hr) } \\
\hline & Free enzyme & Free cell \\
\hline 0 hrs & 00.30 & 00.12 \\
\hline 24hrs & 21.42 & 19.08 \\
\hline 48hrs & 25.30 & 22.56 \\
\hline 72hrs & 13.08 & 11.48 \\
\hline
\end{tabular}

Table.3 Effect of gel concentration on enzyme activity $(\mathrm{mM} / \mathrm{ml} / \mathrm{hr})$.

\begin{tabular}{|l|l|l|l|l|l|l|}
\hline \multicolumn{1}{r|}{$\begin{array}{c}\text { Gel conc. } \\
\text { Time }\end{array}$} & $\begin{array}{c}\text { Immobilized } \\
\text { cells }\end{array}$ & $\begin{array}{c}\text { Immobilized } \\
\text { enzyme }\end{array}$ & $\begin{array}{c}\text { Immobilized } \\
\text { cells }\end{array}$ & $\begin{array}{c}\text { Immobilized } \\
\text { enzyme }\end{array}$ & $\begin{array}{c}\text { Immobilized } \\
\text { cells }\end{array}$ & $\begin{array}{c}\text { Immobilized } \\
\text { enzyme }\end{array}$ \\
\hline Ohrs & $00.02 \pm 0.02$ & $00.02 \pm 0.03$ & $00.01 \pm 0.03$ & $00.04 \pm 0.01$ & $00.03 \pm 0.01$ & $00.01 \pm 0.02$ \\
\hline 24hrs & $14.50 \pm 0.08$ & $18.23 \pm 0.06$ & $11.42 \pm 0.05$ & $16.37 \pm 0.02$ & $05.58 \pm 0.06$ & $11.83 \pm 0.04$ \\
\hline 48hrs & $16.37 \pm 0.05$ & $20.22 \pm 0.04$ & $15.33 \pm 0.07$ & $19.51 \pm 0.08$ & $10.37 \pm 0.04$ & $15.92 \pm 0.08$ \\
\hline 72hrs & $05.33 \pm 0.03$ & $10.13 \pm 0.08$ & $04.08 \pm 0.03$ & $8.073 \pm 0.05$ & $02.14 \pm 0.08$ & $7.739 \pm 0.02$ \\
\hline
\end{tabular}


Table.4 Effect of cell concentration and enzyme concentration on enzyme activity (mM/ml/hr).

\begin{tabular}{|c|c|c|c|c|c|c|}
\hline \multirow{2}{*}{$\begin{array}{l}\text { Coucentration } \\
\text { Time }\end{array}$} & \multicolumn{2}{|c|}{$0.5 \mathrm{ml}$} & \multicolumn{2}{|c|}{$1 \mathrm{ml}$} & \multicolumn{2}{|c|}{$1.5 \mathrm{ml}$} \\
\hline & Cell & Enzyme & Cell & Enzyme & Cell & Enzyme \\
\hline Ohrs & $00.2 \pm 0.02$ & $00.02 \pm 0.01$ & $00.04 \pm 0.03$ & $00.01 \pm 0.02$ & $00.06 \pm 0.02$ & $00.02 \pm 0.01$ \\
\hline $24 \mathrm{hrs}$ & $07.91 \pm 0.05$ & $11.67 \pm 0.03$ & $09.58 \pm 0.01$ & $15.41 \pm 0.05$ & $13.75 \pm 0.01$ & $17.5 \pm 0.02$ \\
\hline $48 \mathrm{hrs}$ & $10.49 \pm 0.03$ & $13.54 \pm 0.02$ & $12.67 \pm 0.03$ & $16.45 \pm 0.04$ & $15.41 \pm 0.08$ & $20.41 \pm 0.06$ \\
\hline 72hrs & $04.58 \pm 0.01$ & $05.13 \pm 0.05$ & $05.83 \pm 0.08$ & $06.38 \pm 0.05$ & $07.08 \pm 0.03$ & $07.78 \pm 0.01$ \\
\hline
\end{tabular}

Table.5 Productivity of immobilized enzyme and immobilized cells in different bioreactors

\begin{tabular}{|c|c|c|c|c|c|c|c|c|}
\hline Time in hrs & FC & FE & \multicolumn{2}{|c|}{ Shake flask } & \multicolumn{2}{|c|}{ Column reactor } & \multicolumn{2}{|c|}{ Airlift reactor } \\
\hline & & & IC & IE & IC & IE & IC & IE \\
\hline Ohrs & 00.12 & 00.30 & $00.02 \pm 0.02$ & $00.02 \pm 0.03$ & $00.03 \pm 0.01$ & $0.01 \pm 0.02$ & $0.03 \pm 0.01$ & $0.02 \pm 0.01$ \\
\hline 24hrs & 19.08 & 21.42 & $14.50 \pm 0.08$ & $18.23 \pm 0.06$ & $07.48 \pm 0.03$ & $14.27 \pm 0.01$ & $17.39 \pm 0.05$ & $23.65 \pm 0.04$ \\
\hline $48 \mathrm{hrs}$ & 22.56 & 25.30 & $16.37 \pm 0.05$ & $20.22 \pm 0.04$ & $10.76 \pm 0.02$ & $16.97 \pm 0.5$ & $22.82 \pm 0.08$ & $27.61 \pm 0.07$ \\
\hline$\overline{72 h r s}$ & 11.48 & 13.08 & $05.33 \pm 0.03$ & $10.13 \pm 0.08$ & $08.15 \pm 0.01$ & $11.03 \pm 0.04$ & $12.71 \pm 0.03$ & $17.38 \pm 0.02$ \\
\hline $\begin{array}{l}\text { Citric acid } \\
\text { (mg/ml) } \\
\text { After } 8 \text { days of } \\
\text { fermentation }\end{array}$ & 102 & 114 & 66 & 78 & 42 & 58.5 & 85.5 & 91.5 \\
\hline
\end{tabular}

Abbreviations: IC- Immobilized cells, IE- Immobilized enzyme, FC- Free cell, FE- Free enzyme

Fig.1 Effect of gel concentration using Immobilized cells on enzyme activity. Immobilized enzyme on enzyme activity. Fig.2 Effect of gel concentration using immobilized cells on enzyme activity. Immobilized enzyme on enzyme activity

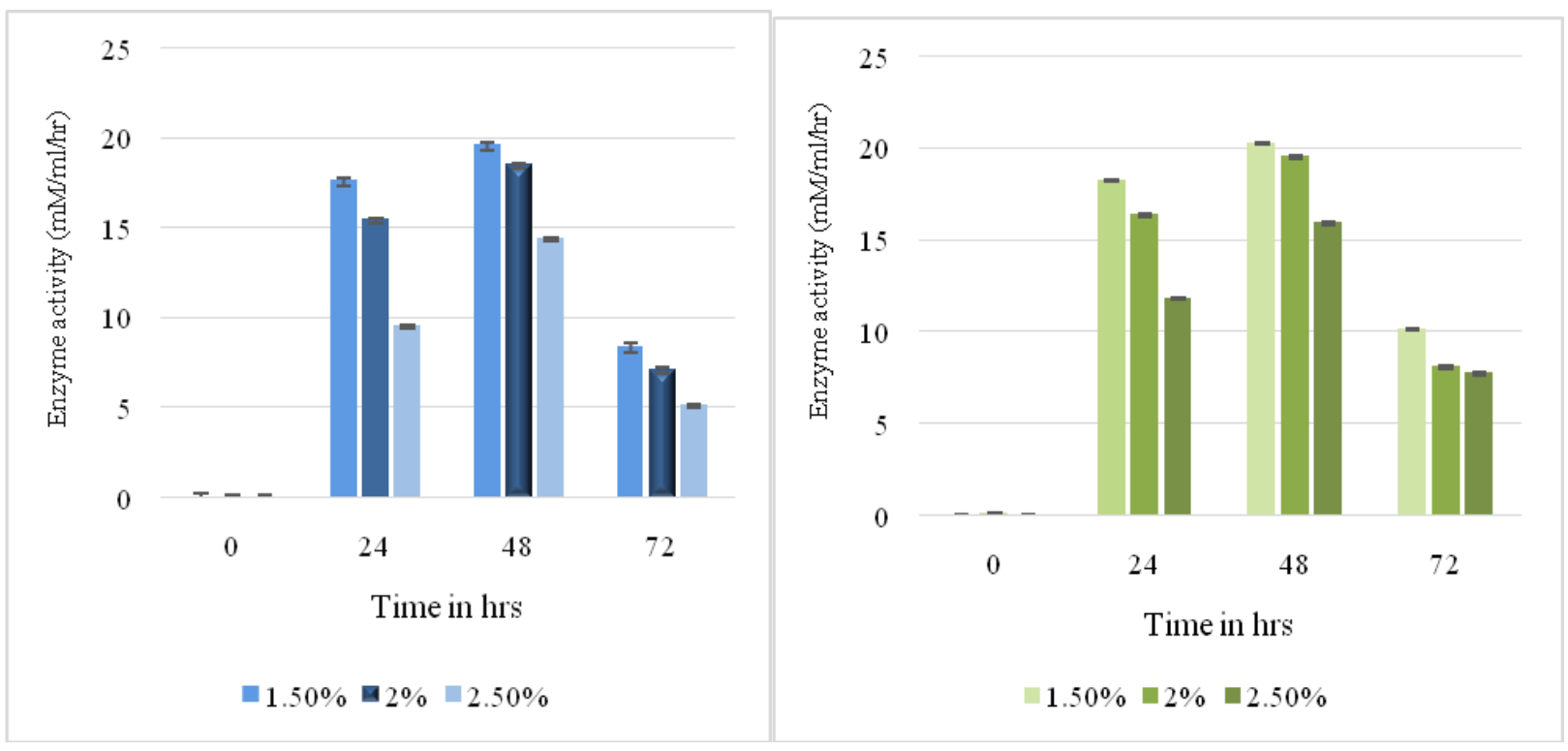


Fig.3 Effect of cell concentration on enzyme activity. Fig.4 Effect of enzyme concentration on enzyme activity
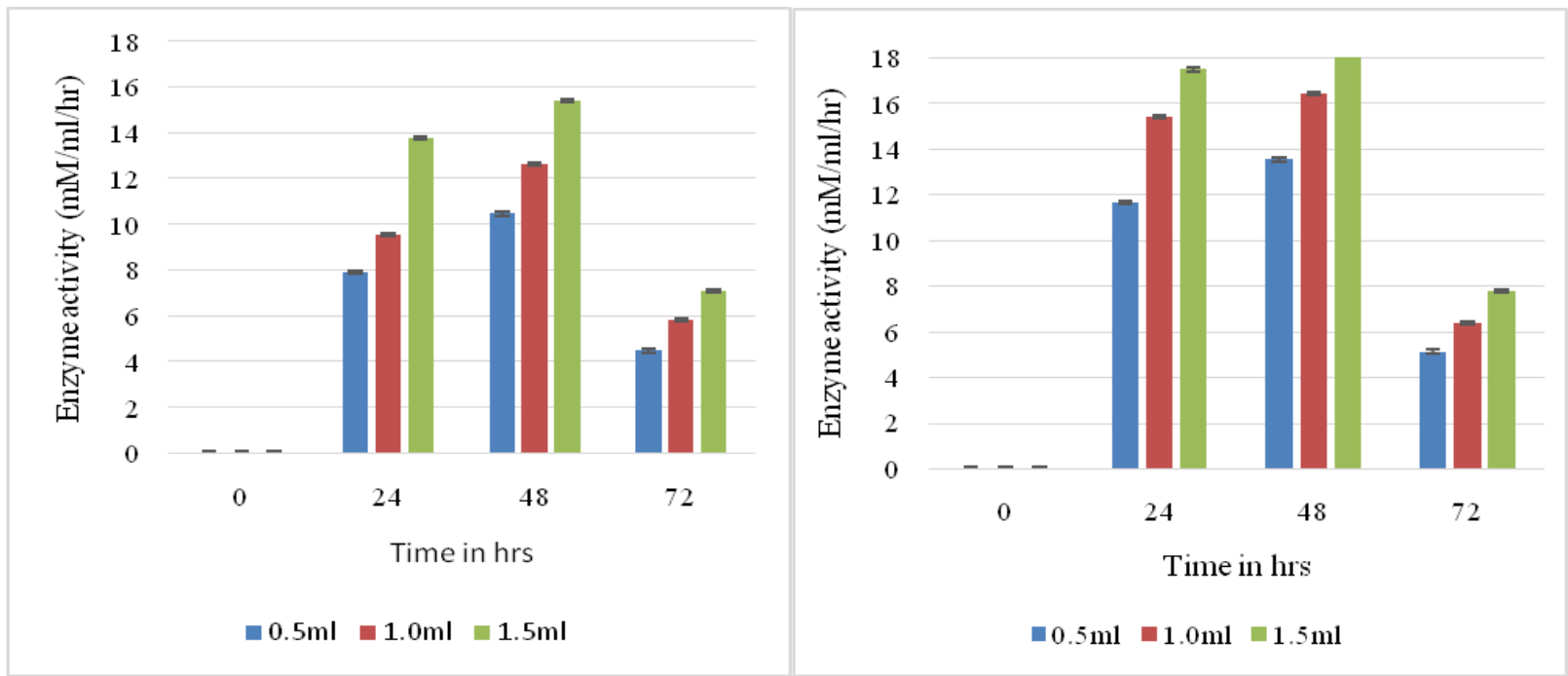

Fig.5 Effect of $\mathrm{pH}$ on enzyme activity

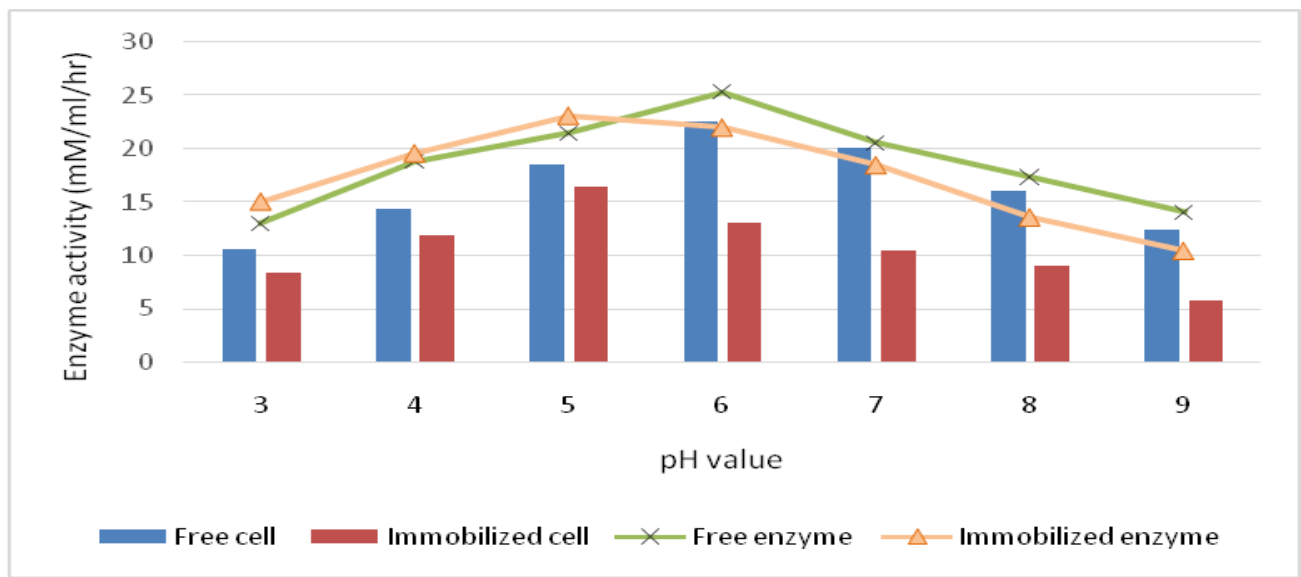

Fig.6 Effect of temperature on enzyme activity

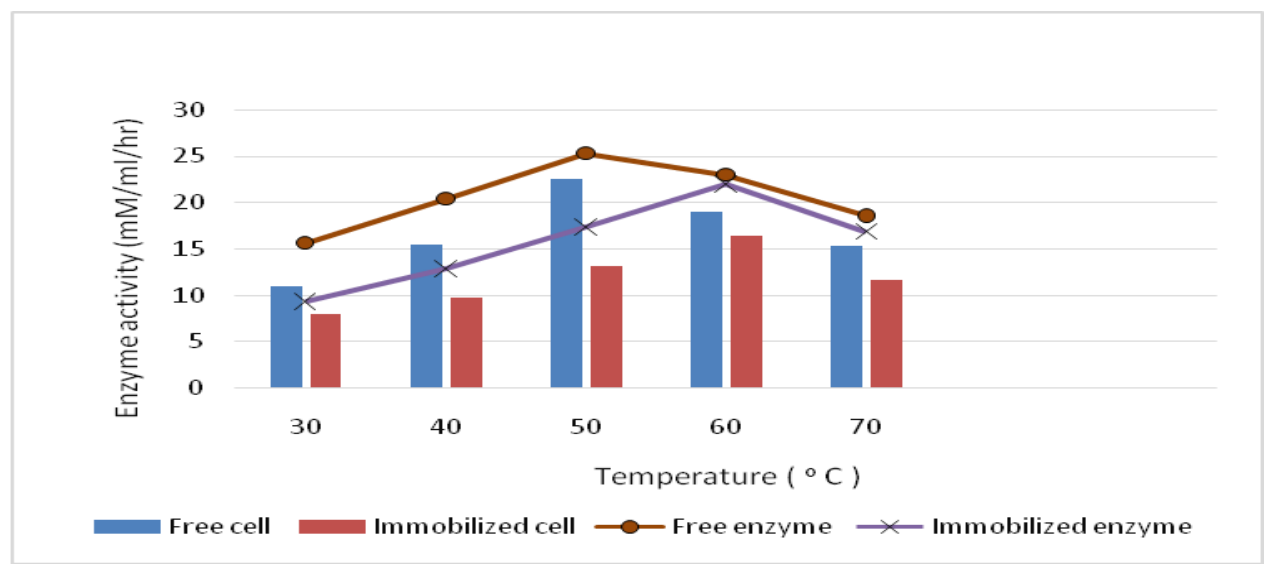


Fig.7 Reusability of immobilized cells and enzyme

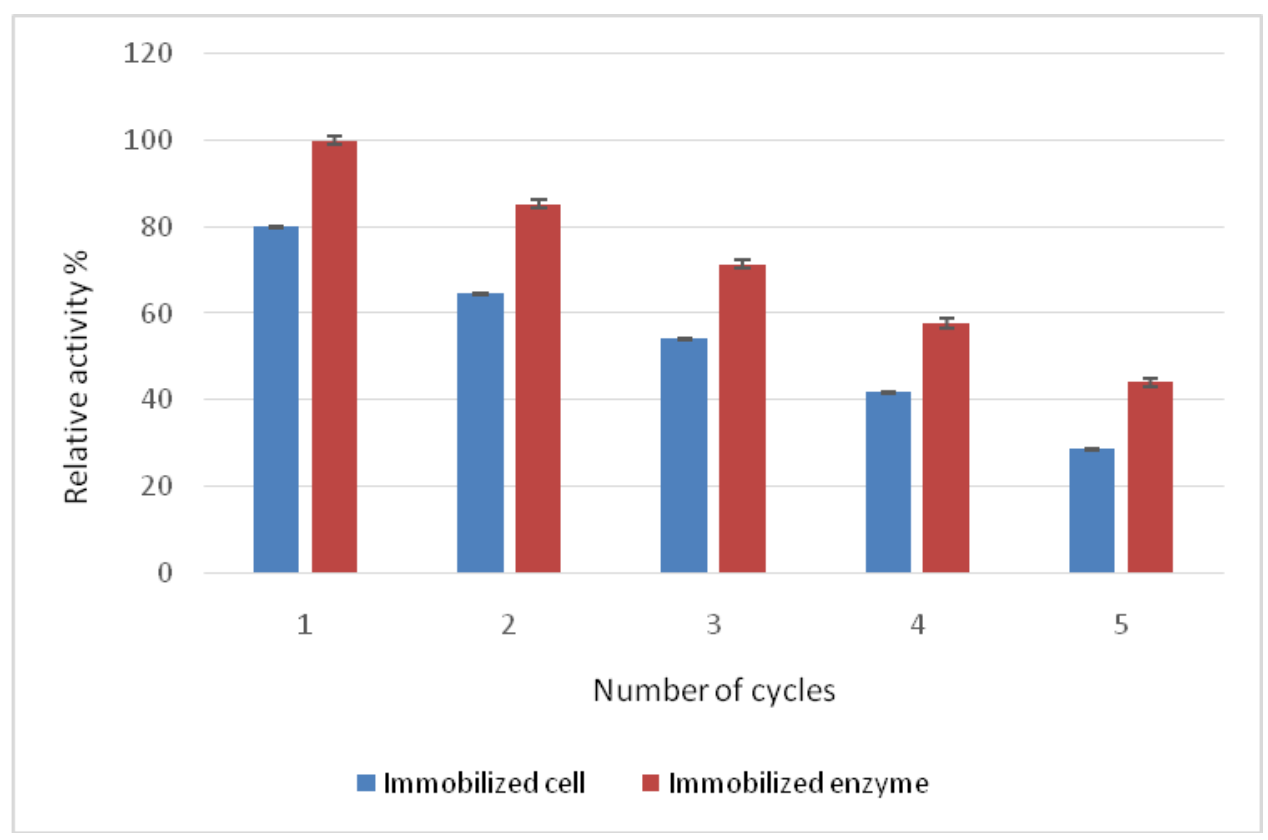

Effect of gel concentration on enzyme activity

It is been reported that the yield of immobilized enzyme depends on the concentration of sodium alginate. Various concentrations of sodium alginate were used to prepare beads. The yield was found to be the highest at $1.5 \%$ concentration of sodium alginate (Table 3). The activity of immobilized enzyme (Fig. 2 and 3) was high as compared to immobilized cells by $23.51 \%$ (Fig. 1). The activity of immobilized enzyme was found to be equal when compared to the work done by Mohammed Abdu Al-ZaZaee et al., (2011).

\section{Effect of cell concentration and enzyme concentration on enzyme activity}

It was studied that the activity of enzyme and cell depends upon its concentration. The activity of enzyme (Fig. 4) and cell (Fig. 3) was observed to be high i.e., $20.41 \mathrm{mM} / \mathrm{ml} / \mathrm{hr}$ and $15.41 \mathrm{mM} / \mathrm{ml} / \mathrm{hr}$ respectively at $1.5 \mathrm{ml}$ of their concentration when incubated for $48 \mathrm{hrs}$ and decreased on further incubation. The activity of enzyme was found to be high as compared to cell by $33.3 \%$ (Table 4 ).

\section{Effect of pH on enzyme activity}

The optimum $\mathrm{pH}$ for free cell and free enzyme was observed to be 6.0. After immobilization the optimum $\mathrm{pH}$ decreased to 5.0. In high alkaline and acidic conditions immobilized cells and enzyme did not show expected activity (Fig. 5). When compared with the studies done by Basabrani Devi et al., (2012), the optimum $\mathrm{pH}$ of immobilized cells and enzyme was found to be more.

\section{Effect of temperature on enzyme activity}

The optimum temperature for free cell and free enzyme was observed to be $50^{0} \mathrm{C}$, after immobilization the optimum temperature increased by $10^{0} \mathrm{C}$ (Fig. 6). When compared with the studies done by EsawyMona Abdeltawab et al., (2014), the optimum temperature of immobililzed cells and enzyme was found to be high. 
Productivity of immobilized enzyme and immobilized cells in different bioreactors

The activity of immobilized enzyme was high as compared to immobilized cells by $23.51 \%$. The productivity was then checked using different bioreactors. The enzyme activity was found to be highest in the Air Lift Reactor then Shake Flask and lowest in Column Reactor. The enzyme activity of the immobilized enzyme in the Air Lift Reactor was found to be $20.99 \%$ more when compared with the activity in the Shake Flask. Citric acid production from $20 \%$ starch using free enzyme and free cell was found to be $76 \%$ and $68 \%$ respectively after 8days of fermentation. Citric acid production by immobilized enzyme in airlift reactor was found to be $38.63 \%$ more when compared to shake flask (Table 5).

\section{Reusability of immobilized cells and immobilized enzyme}

The main advantage of immobilization is its reusability. Its use is also cost effective in industries. The immobilized cells or the enzyme can be reused after separation by filtration. The reusability of the immobilized cells and enzyme was studied up to 5 cycles. It was found that the activity and reusability of immobilized $\alpha$-amylase was high as compare to that of immobilized cells producing $\alpha$-amylase. The activity of immobilized enzyme decreased to $43 \%$ after $5^{\text {th }}$ cycle which was low as compared to the work done by Talekar Sachin et al., (2012). The activity of immobilized cells decreased to $28 \%$ after $5^{\text {th }}$ cycle as shown in the figure 6 .

The enzyme activity of free enzyme was high as compared to that of free cell. Highest activity was observed at $48 \mathrm{hrs}$ of incubation and declined then after. The activity of immobilized enzyme was high as compared to that of immobilized cells by $23.51 \%$ at $1.5 \%$ of gel concentration. The enzyme activity increased with the increase in cell and enzyme concentration. It was high at $1.5 \mathrm{ml}$ of cell and enzyme concentration. Immobilized enzyme and cells showed great stability at high temperature i.e., $60^{\circ} \mathrm{C}$ and $\mathrm{pH}$ 5.0.The productivity of immobilized cells and enzyme was high in Air lift reactor than in shake flask and column reactor. The activity of immobilized cells and enzyme decreased upto $28 \%$ till $5^{\text {th }}$ cycle. Citric acid production by immobilized enzyme in airlift reactor was found to be $38.63 \%$ more when compared to shake flask. The optimization of bioreactor parameters are still to be worked on for efficient utilization of the unconventional method for production of citric acid from starch for further scale-up and pilot plant studies.

\section{References}

Abdu Al- ZaZaee Mohammad, Neelgund Shivayogeshwar and Achur Rajeshwara N., (2011), Immobilization of Halophilic $\alpha$ - Amylase from Bacillus Cereus MS6 Bacteria and its Characterization, International Journal of Applied Biotechnology and Biochemistry, 4, 361-374.

Ahmad Razi and SardarMeryam, (2015), Enzyme Immobilization: An Overview on Nanoparticle as Immobilization Matrix, Biochemistry \& Analytical Biochemistry, 4, 178.

AzharMohsin, UniyalVeena, Chauhan Neha and RawatDevendra Singh, (2014), Isolation and Biochemical characterization of Halophiles from Sahastradhara region, Dehradun, India, International Journal of Current Microbiology and Applied Sciences, 3(12), 753-760.

Bholay A. D, KoltePurva and PatilKarishma, (2016), Alkaline Protease Immobilized Cells An Effective Tool For Biofilm 
Degradation, Journal For Advance Research In Applied Sciences, 3, 235245.

BrenaBeratriz M. and Viera- Francisco Batista, (2006), Immobilization of Enzymes: A Literature Survey, Methods in Biotechnology, XIV -450.

Devi Basabrani, B.G. Unni, Wann S.B. and Samanta R., (2012), Immobilization of partially purified alpha-amylase enzyme produced by a soil born Bacillus sp., Pelagia Research Library, 2(5), 27362744.

Esawy Mona Abdeltawab, Kansoh Amany Lotfy, Kheiralla Zenaib Hassan, Ahmad Hala AbhElmonem, Kahal Tartek AlyKamal, and Abd El-Hameed Eman Karam, (2014). Production and Immobilization of halophilic invertase produced from honey isolate Aspergillus niger EM77 (KF774181), International Journal of Biotechnology for Wellness Industries, 3, 36-45.

IrshadAarzoo, Ahmad Irshad and Kim Seung Bum, (2013), Isolation, Characterization and antimicrobial activity of halophilic bacteria in foreshore soils, African Journal of Microbiology Research, 7(3), 164-173.

KiranKanthi K, Koteshwaraiah Podili and Chandra T.S., (2012), Production of Halophilic $\alpha$-Amylase by Immobilized Cells of Moderately Halophilic Bacillus sp. Strain TSCVKK, British Microbiology Research Journal, 2(3), 146-157.

Kumar Sumit, Grewal Jasneet, Sadaf Ayesha, Hemamalini R. and Khare Sunil K, (2016), Halophiles as a source of polyextremophilic $\alpha$-amylase for industrial applications, AIMS Microbiology, 2(11), 1-26.

Lahiri Preeti, (2015), Development of the Optimal Conditions fir Alpha-Amylase Immobilization, International Journal of Scientific Research, 4, 500-502.
Maheswari Uma N and Priyadharshini Indra S, (2014), Effect of different immobilization techniques on $\alpha$ amylase, Journal of Chemical and Pharmaceutical Research, 6(5), 768774.

Mostafa Yasser S. and AlamriSaad A., (2014), Biosynthesis of thermostable $\alpha$ Amylase by immobilized Bacillus subtilus in batch and repeat batch cultures using fortified date syrup medium, African Journal of Microbial Research, 8(12), 1292-1301.

Nisha S, Arun Karthick S and Gobi N, (2012), A Review on Methods, Applications and Properties of Immobilized Enzyme, Chemical Science Review and Letters, 1(3), 148-155.

Pandey. P, Putatunda S, Dewangan L, Pawar V. S and Belorkar S. A, (2013), Studies on citric acid production by Aspergillus niger in batch fermentation, Resent Research in Science and Technology, 5(2), 66-67

Prabakaran G, Pugalvendhan R., (2009), Production and Immobilization of Alpha Amylase by using Bacillus subtilus, Recent Research in Science and Technology, 1(4): 189-194.

Raghu, H.S. and Rajeshwara, N.A., (2015), Immobilization of $\alpha$-amylase (1, 4- $\alpha$-DGlucanglucanohydralse) by calcium alginate encapsulation, International Food Research Journal, 22(2), 869-871.

Singh Pushpendra, Gupta Paras, Singh Ravendra, and Sharma Rajesh, (2012), Activity and Stability of Immobilized alpha-amylse produced by Bacillus acidocaldarius, International Journal of Pharmacy and Life Sciences, 3, 22472253.

Suman S, and Ramesh K., (2010), Production of a Thermostable extracellular amylase from thermophilic Bacillus species, Journal of Pharmaceutical Sciences and Research, 2(2): 149-154. 
Suribabu. K, Govardhan Lalitha. T, Hemalatha K. P. J, (2014), Characterization of $\alpha$-amylase producing Bacillus mycoides strains from Bay of Bengal Vishakhapatnam, International Journal of Pure and Applied Bioscience, 2(1), 266-271

TalekarSachin and Chavare Sandeep, (2012), Optimization of immobilization of $\alpha$ amylase in alginate gel and its comparative biochemical studies with free $\alpha$-amylase, Recent Research in Science and Technology, 4(2), 01-05.

Tavano Olga Lusia, Lafuenta Roberto Fernandez, Goulart, Antonio Jose,
Monti Reubens, (2013), Optimization of the immobilization of sweet potato amylase using glutaraldhyde- agarose support, Characterization of the immobilized enzyme, Process Biochemistry, 1054-1058.

TodkarSandip, TodkarRohit, KowaleLeena, KarmakarKirti, Kulkarni Arvind, (2012), Isolation and Screening of Antibiotic producing Halophiles from Ratnagiri costal area, State of Maharashtra, International Journal of Scientific and Research Publications, 2, 01-03.

\section{How to cite this article:}

Bholay, A.D., Deshmukh Swateja Sanjay and Joseph Angeline Wilson. 2018. Immobilized Polyextremophilic $\alpha$-Amylase of Bacillus mycoides for Citric Acid Production Using Starch. Int.J.Curr.Microbiol.App.Sci. 7(03): 3055-3065. doi: https://doi.org/10.20546/ijcmas.2018.703.355 